\title{
第亚部 研究委員会の動向
}

\section{II 特別研究会・アドホック研究会・ミニ研究会の動向}

\section{特別研究会 \\ 「建築鉄骨柱梁溶接接合部における溶融亜鉛めっき割れに関する研究」 \\ 護 雅典*，中込 忠男**，藤田 哲也*** \\ Experimental Study on Crack of Hot Dip Galvanaized Coatings of Welded Joint of Beam-to-Column Connection}

by MORI Masanori* , NAKAGOMI Tadao** and FUJITA Tetsuya***

キーワード：建築鉄骨柱梁接合部, 溶融亜鉛めつき割れ, スカラップ形状，めっき抜き孔，CEZ

\section{1 はじめに}

建築鉄骨溶接特別研究会は建築鉄骨にかかわるテーマ を検討してきた。過去には，「パス間温度と溶接入熱量の 効率的管理」「電炉 $\mathrm{H}$ 形鋼の溶接性能について」などを テーマとしてきたが，今回は，建築鉄骨に扔ける溶融車 鉛めっき割れ（以下，めっき割れと略す）を取り上げた。

建築鉄骨柱梁溶接部のスカラップ部分でめっき割れが発 生していることが報告されているが，公式に発表されてい るケースは少ない。めっき工場にてめっき割れ発生が報告 されたとしても,めっき作業の発注者がそのまま引き取り, その部分を手直ししてしまうケースが多く，詳細な発生状 況や，発生原因が明らかになっているとはいえない.

建築鉄骨工事の標準的仕様書である日本建築学会標準 仕様書鉄骨工事 JASS6，同鉄骨工事技術指針では，鋼材 単体ないしリブプレートのような簡単な部品が取り付く 状態を念頭において溶融亜鉛めっきの施工手順，検査な どが記述されているにすぎず，また，検査項目に「めっ き割れ」についての記述は無い。従って上記のような柱 梁溶接部に対応できていないのが現状である.

このような状況を踏まえ，溶接学会特別研究会「建築 鉄骨に扔ける溶融亜鉛めっき割れに関する研究」（主査： 中込忠男）においては，建築鉄骨におけるめっき割れの 発生状況確認, 発生要因の整理, 溶接部ディテールとの 関係等を実験的に把握することを研究目的として活動を 行っている.

\section{2 活動内容}

本研究会は 2004 年 9 月から実質的活動を始めた。研究 会の委員は, 大学研究者, 学識経験者, 設計者, ゼネコ ン，ファブリケーター，めっき会社，検査会社など建築

\section{原稿受付 平成 18 年 5 月 1 日}

*正 員 (株) 竹中工務店 Member, Takenaka Corp.

**正 員 信州大学 Member, Shinshuu University

***正 員 日本設計 Member, Nihon Sekkei Inc.
鉄骨のめっきにかかわる多くの分野から参画している. ここでは，これまでの活動内容と結果の一部を紹介する.

\subsection{1 文献調查}

めっき割れに関しては送電鉄塔用鉄骨材料の開発にお いて多くの研究が行われ，その結果はJIS に結実してい る. 文献としては，これに関して多くのものがあること が再認識された。しかしながら建築鉄骨で多用される引 張強度 $400 \mathrm{~N} / \mathrm{mm}^{2}$ (以下， $400 \mathrm{~N}$ と略す)， $490 \mathrm{~N} / \mathrm{mm}^{2}$ （以下， $490 \mathrm{~N}$ と略す）級鋼材についてはほとんど無い, あるいは，鉄塔用鋼材開発の過程において，引張強度 490N以下の鋼材ではめっき割れは生じないとして研究対 象から外れていることがわかった.

\subsection{2 めっき割れの実態}

1.1 で述べたように現実の工事ではめっき割れの報告が ある。しかしながら，めっき作業の発注者がそのまま引 き取る，補修するなどでめっき割れの現物が残っていな い事がほとんどで，写真，あるいは担当者の記憶のなか にしか残っていない事がわかった。 結果として，その原 因について調査・検討した実例が少ないことがわかった。 図 1 に委員から提出されためっき割れの実例を示す.

\subsection{3 めっき割れ再現実験と結果}

研究を進めるにあたり，めっき割れの現物がなければ ならないということで，めっき割れの再現実験を計画・ 実施した。めっき作業における各種要因を「めっき割れ
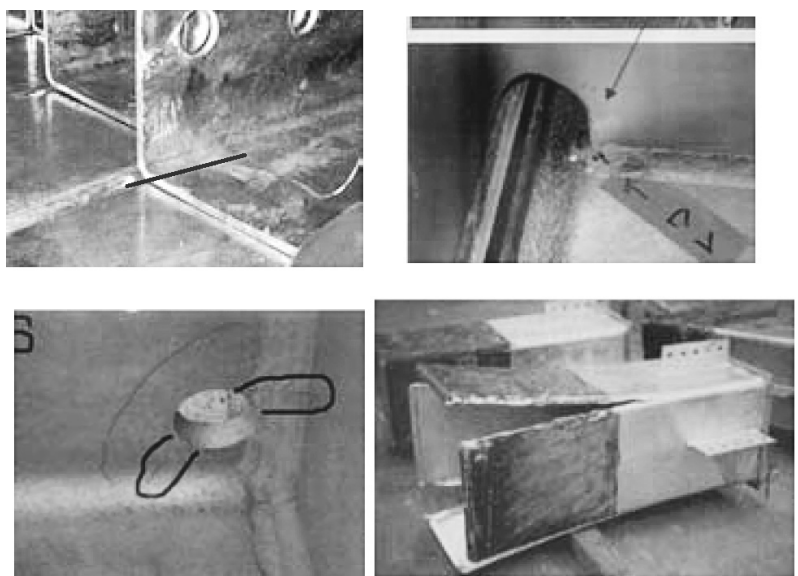

図 1 めつき割れの実例 


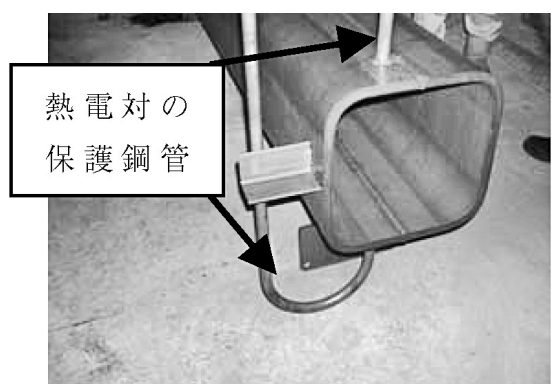

図2 鋼管試験体

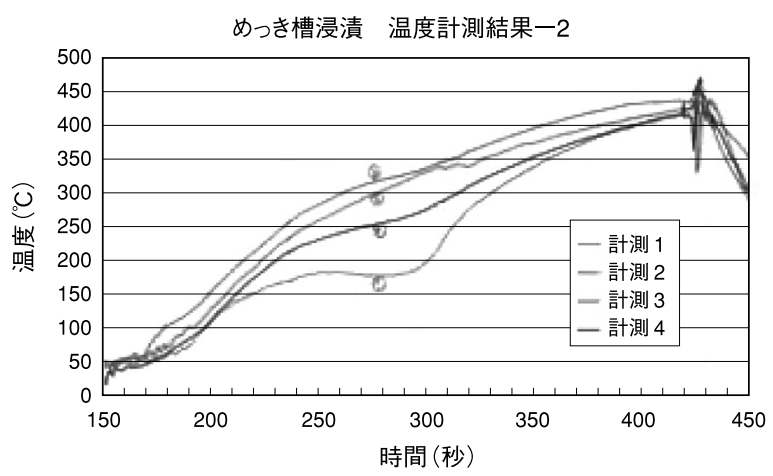

図 3 温度測定結果

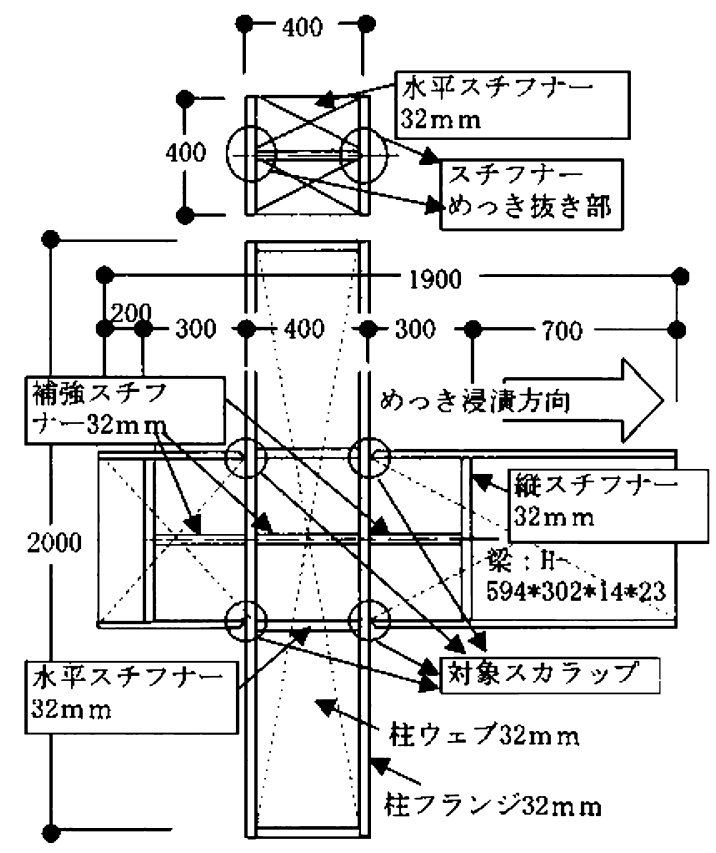

図 4 試験体形状

を発生させる可能性が高くなる」ように組合せ，実験を 計画した．以下，実験の概要と結果の一部を紹介する.

(1) 角形鋼管

冷間成形角形鋼管 $\square-400 \times 400 \times 22$, 長さ $3 \mathrm{~m}$ ，（引張 強度は $490 \mathrm{~N}$ 級）を素管のままめっきを行い，めっき割 れ発生の有無を確認した。めっき割れ発生を促す目的で 角部にわざとショートビードをおいた。 また，めっき時 の温度を測定するため鋼管の両端 4 箇所に熱電対を取り 付けた. 熱電対の設置状況を図 2 示す.

めっき後，磁粉探傷によりめっき割れの確認を行った がめっき割れは無かった。図 3 に温度測定の結果を示す.

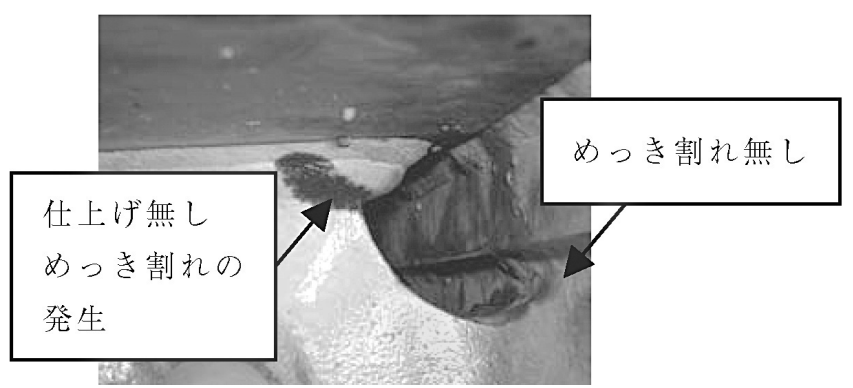

図 5-1 改良形スカラップ周辺

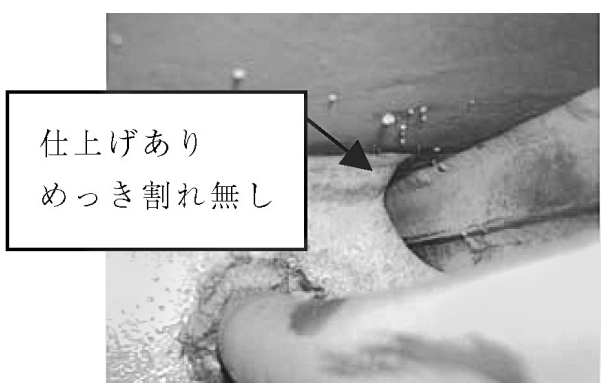

図 5-2 改良形スカラップ周辺

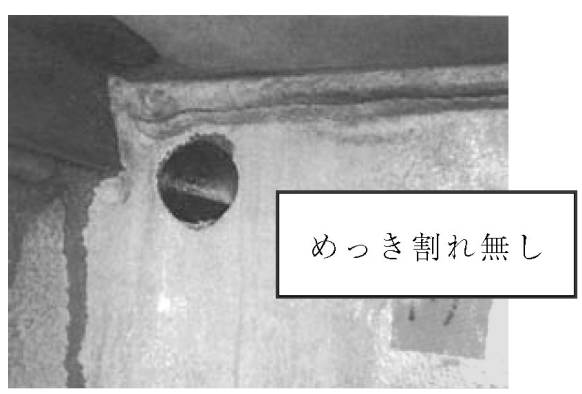

図 6 ノンスカラップ: 丸孔方式

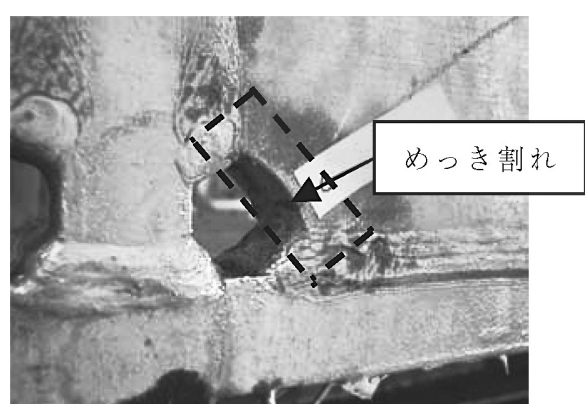

図 7 母材部のめつき割れ

$250 \sim 300^{\circ} \mathrm{C}$ にめっき浴中で鋼管の周辺に固体亜鉛が生成 していることを思わせる温度変化が得られた。この結果 は FEMによる温度解析でも凡そ再現することが出来た.

(2) 柱梁接合部

図 4 に示すような柱梁接合部を模した実大の試験体を 作成し，再現試験を行った。

主な実験要因は, 柱梁接合部のスカラップの形状（改 良形スカラップ, ノンスカラップ), 回し溶接止端部の仕 上げの有無，めっき抜き孔形状の違いである.ここでも 梁の端部，スカラップ近傍でめっき時の温度測定を行っ ている. 鋼材の引張強度は梁 $400 \mathrm{~N}$, 柱 $490 \mathrm{~N}$ である.

めっき後, 浸透探傷試験を行いめっき割れの有無を確 認した。その結果の一例を図 5 〜図 7 に示す. 


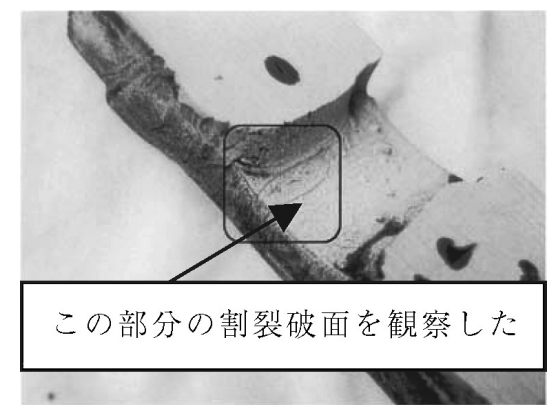

図 8 破面観察用試験片

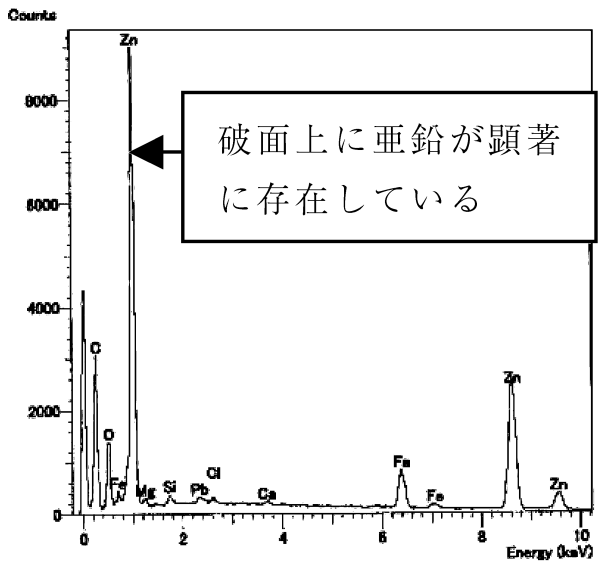

図 9 EDX による定性分析結果

その結果

・ノンスカラップの場合，フランジに滑らかに接して いる側にめっき割れは無かった.

・スチフナーの角部めっき抜き孔周辺の回し溶接止端 部を仕上げない場合，めっき割れが発生していた。

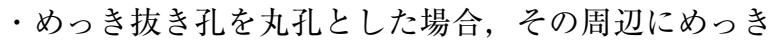
割れの発生は無かった。

図 4 の柱端部水平スチフナーめっき抜き部で，溶接止 端部からやや離れた母材部にめっき割れが認められた (図 7 に示す). めっき割れ部分を含むように図 7 の破線 に沿って切り出し，この破面について走查型電子顕微鏡
(SEM) による観察とエネルギー分散型 X 線分析装置 （EDX）による破面付着物の定性分析を行った。

図 8 は, 図 7 の破線部分の切り出し後に行った浸透探 傷試験でのめっき割れ位置を示す.

図 8 に示されためっき割れ部分を冷却して割裂し，そ の破面をEDXにより分析した.

図 9 に EDXの結果を示すが破面内に亜鉛が検出され, めっき工程中でのめっき割れと考えることができる.

\section{3 おわりに}

今回，建築鉄骨に多用される $400 \mathrm{~N} \cdot 490 \mathrm{~N}$ 級鋼材を使 用しめっき割れの再現実験を行った. 温度解析, 応力解 析など詳細な検討については現在継続中であるが, めっ き割れの発生について何らかの傾向・原因はつかめたの ではないかと考えている.ただし, 今回取り上げること のできなかった要因も多く, 今後の課題としたい. 特に, 鋼材厚の組合せや $400 \mathrm{~N} \cdot 490 \mathrm{~N}$ 級鋼材における溶融覀鉛 めっき割れ感受性当量 (CEZ) の適用範囲の検討はめっ き割れを事前に防ぐ有用な情報となりうると考える.

本研究会の研究を契機とし，建築鉄骨においても実験 や研究が進むことを期待したい. 研究を進めるにあたり, 試験体製作・めっき作業で侏デンコーの中島氏，温度測 定・ひずみ測定・破面観察で住友金属テクノロジー(株の 緒方氏に多大な協力をいただいた。両氏をはじめ, 本研 究会に対しご支援いただいた溶接学会, 委員会活動にご 協力をいただいた委員各位に感謝の意を表します.

\section{文献}

1）（社）日本鋼構造協会：建築用溶融亜鉛めっき構造物の手引き（改 訂版), 2002.2 .

2）（株）巴コーポレーション・(株)巴技研：一解説一溶融亜鉛めっき 大型構造物のめっき割れ現象とその防止法, 2001. 1.

3）（社）日本建築学会：建築工事標準仕様書 JASS6，1996.

4) 小山ら：鉄骨仕口スカラップの溶融亜鉛めっき割れに関する検討, 溶接学会論文集，第22巻，第 3 号，2004.

5) 武田：亜鉛めっき割れ評価法, 溶接学会誌, 第 71 巻, 第 4 号, 2002. 